\title{
The Book Worlds of East Asia and Europe, 1450-1850: Connections and Comparisons, written by Joseph P. McDermott and Peter Burke
}

\section{Citation}

Blair, Ann. 2017. Review of Joseph P. McDermott and Peter Burke, eds., The Book Worlds of East Asia and Europe 1450-1850. Connections and Comparisons. Hong Kong: Hong Kong University Press, 2015. East Asian Publishing and Society 7: 75-78.

\section{Permanent link}

http://nrs.harvard.edu/urn-3:HUL.InstRepos:40986239

\section{Terms of Use}

This article was downloaded from Harvard University's DASH repository, and is made available under the terms and conditions applicable to Open Access Policy Articles, as set forth at http:// nrs.harvard.edu/urn-3:HUL.InstRepos:dash.current.terms-of-use\#OAP

\section{Share Your Story}

The Harvard community has made this article openly available. Please share how this access benefits you. Submit a story.

Accessibility 
Final manuscript for DASH of Ann Blair, Review of Joseph P. McDermott and Peter Burke, eds., The Book Worlds of East Asia and Europe 1450-1850. Connections and Comparisons. Hong Kong: Hong Kong University Press, 2015. East Asian Publishing and Society 7 (2017), 75-78

Joseph P. McDermott and Peter Burke, eds. The Book worlds of East Asia and Europe, 1450-1850: connections and comparisons. Hong Kong: Hong Kong University Press, 2015. \$80. ISBN 978-988-8208-08-1.

Book history has been thriving in recent decades, inspiring studies of the production, distribution, reception, and survival of texts in different material forms and across an ever broader range of time/place contexts. We now have many handbooks in the field, often defined by national context, and an impressive accumulation of research in many areas, including early modern Europe, which was the first focus of the field, and pre-modern East Asian contexts, where printing was first developed. This excellent volume brings into dialogue book historians expert in these two fields, offering both an efficient pathway into the latest scholarship and a thoughtful assessment of the connections and comparisons that can be drawn between them.

A masterful first chapter by the editors addresses some of the long running debates about the exchanges between Europe and East Asia before 'modern' contact in the mid- $19^{\text {th }}$ century. They reach sobering conclusions about the extent of cross-cultural transfers of technology, books, ideas, and people. In particular McDermott and Burke find no evidence for the claims that printing spread westward from China to Europe before the $15^{\text {th }}$ century, or that China and Europe had fused their scientific knowledge in the $17^{\text {th }}$ or $18^{\text {th }}$ centuries, as Joseph Needham had advanced in his multivolume work on Science and Civilisation in China. People made the journey in both directions - missionaries and merchants from Europe to China and about one hundred Chinese men from China to Europe for seminary study (p. 50), relaying ideas orally and in manuscript with effects that are hard to measure. Printed books travelled, too, surviving in libraries today or in records of their travels. But few could read the Chinese books that reached Europe or vice versa, though illustrated volumes could be appreciated nonetheless. Translations were rare: the Confucian classics were translated into Latin and the Bible into Chinese only in the late $17^{\text {th }}$ century, and the latter was never printed. The Jesuits also translated and printed about 120 books on scientific topics, but omitted many topics of current debate in Europe such as Copernicanism. Travel narratives were often fanciful; it was principally Matteo Ricci's writings which conveyed a well-informed account of China to a wide European audience (printed in eleven editions and seven languages). News of the Qing conquest of 1644 was also widely diffused in Europe (though in some cases up to a decade later), and news from Europe reached government officials in China and Japan though only to the extent that they sought it out. In short the 'globalization' which we associate with the early modern period did not imply easy or substantial transfer of ideas, techniques, books, or people. Developments in Europe and East Asia 1450-1850 were more often parallel than directly interconnected. And yet this volume shows how fruitful 
is the contact among specialists of these two separate cultural areas as they address common themes, notably on the production, distribution, and reception of books. This edited volume originated at a small conference in which each of the six authors became well acquainted with the work of the others, to which they refer for comparisons.

Comparisons between East Asia and Europe on the impact of printing must first note that we commonly use one word, 'printing', to describe multiple techniques for the mechanical reproduction of texts, including: xylography (by woodblock), typography (by moveable type), lithography (by chemicals applied to a stone surface), and technologies of digital publication today. Before the spread of lithography in the mid- $19^{\text {th }}$ century, printing in Europe involved different constraints from the dominant form of printing in East Asia. European printing by moveable type required significant capital investment to pay for a complete print-run in advance of any sales, and a good location (typically a major mercantile center) from which to distribute the books. By contrast, woodblocks could be carved almost anywhere at relatively low cost and could be used to make copies on demand, though the storage of woodblocks for future reprinting could be a burden.

The consequences of these technical differences are many. Bibliographical description of Western books focuses on the identification of editions produced by the same setting of type (allowing for small variations due to stop-press corrections). In the East Asian case identifying an edition is much more difficult, since copies from the same woodblock could be printed years, decades, or even centuries apart. In Chapter Two, David McKitterick lays out the complexity of estimating the number of books printed in Europe, by critiquing the ambitious estimates made by the economic historians Buringh and van Zanden. Such estimates for the Chinese case are even more difficult, since there is, as yet, no census of surviving books (as there is for books printed in Europe before 1600 and for English books down to 1800). In Chapter Three, Joseph McDermott emphasizes another major difference between European and Chinese printing. European printing was mostly commercial from the beginning whereas in China non-commercial printing predominated until the $16^{\text {th }}$ century, as most books were funded by temples, or government offices, or privately by families or individuals. The contrasts highlighted in this pair of articles invite specialists in both areas to attend to parallels in their own. In particular, Europeanists might find more non-commercial printing too if they were more attentive to it (indulgences come to mind for example); in both contexts, manuscript circulation continued to play an important role in the circulation of ideas and texts.

The following two articles contrast patterns of distribution. James Raven explains the constraints on European systems of distribution followed by their relative liberalization starting in the late $17^{\text {th }}$ century. First, Raven notes that books were also diffused noncommercially - through gifts, distribution of propaganda, and the seizures in war, for example. But European printers could survive only if they sold their stock efficiently. In the Hansa (Hanseatic) model, merchants travelled with their wares to fairs; in the 'branch' model, wholesalers contracted with branches in major cities to facilitate sales. But Raven rejects a linear portrayal of the expanding market, noting that relative to rising 
incomes books became more, not less, of a luxury in $18^{\text {th }}$-century Britain (p. 232); they reached the same audiences in greater numbers rather than the 'new readers' associated with the $19^{\text {th }}$ century (including workers especially). The paired essay by Cynthia Brokaw emphasizes the difficulties of book distribution in China by examining three different settings --a successful market town (Xuwan), an isolated printing center (Sibao), and a site of peasant blockcutters (Yuechi). In contrast with Europe, she notes the lack of market regulation, the greater distances to cover, and the trends toward decentralization. But she notes a parallel expansion of markets by mid $17^{\text {th }}$ century driven by population growth and the role of printing in favoring social and cultural integration.

The third pair of articles focuses on the consumption of books. Peter Burke studies reference books, contrasting the 'bureaucratic organization of knowledge' in China with the more entrepreneurial system prevalent in Europe and Japan. Some of China's most remarkable reference books were commissioned by the emperor and were never meant to be sold or circulated. But how-to books (and in China exam preparation manuals) were successful commercial genres in both contexts. Peter Kornicki, an expert on the book in Japan, studies attitudes toward women readers and concludes that Europeans articulated more anxiety about women reading than East Asian moralists. Indeed, courtesans were portrayed with books to enhance their desirability. As authors, women were mainly active in poetry in both China and Japan and often circulated their work in manuscript for consumption in poetry circles.

In the epilogue McDermott and Burke highlight the sea changes that have recently transformed the world of books, noting nonetheless some continuities from the period before 1850 - e.g. in the bookish terms that electronic processes still use, or the strong role of government in publishing in China today, or the higher valence of printed matter in China than in Japan. The book closes with a helpful bibliographic essay and index, inviting others to follow in the path opened here of carefully grounded comparisons between Europe and East Asia. These 'book worlds' before 1850 were not globalized; they offer separate yet parallel cases through which we can better understand how multiple factors (technical and geographical, political and cultural) shaped the production, distribution, and consumption of books.

Ann Blair

Department of History, Harvard University amblair@fas.harvard.edu 